\title{
Extractive Spectrophotometric Method for Determination of Molybdenum in Steels and Environmental Samples
}

\author{
Rameshwar Dass, ${ }^{1}$ Jitander K. Kapoor, ${ }^{2}$ and Sunita Gambhir ${ }^{3}$ \\ ${ }^{1}$ Department of Industrial Chemistry, Guru Nanak Khalsa College, Yamuna Nagar, Haryana 135001, India \\ ${ }^{2}$ Department of Chemistry, National Institute of Technology, Kurukshetra, Haryana 136119, India \\ ${ }^{3}$ Department of Chemistry, Arya Kanya Mahavidyalya, Shahabad (M), Haryana 136135, India
}

Correspondence should be addressed to Sunita Gambhir; sunitapahwa62@gmail.com

Received 16 January 2012; Accepted 13 June 2012

Academic Editor: Beatriz Royo

Copyright (C) 2013 Rameshwar Dass et al. This is an open access article distributed under the Creative Commons Attribution License, which permits unrestricted use, distribution, and reproduction in any medium, provided the original work is properly cited.

An extractive spectrophotometric method has been developed for microdetermination of molybdenum. At room temperature $\mathrm{Mo}(\mathrm{VI})$ was reduced to $\mathrm{Mo}(\mathrm{V})$ in $2 \mathrm{M} \mathrm{H}_{2} \mathrm{SO}_{4}$ using ascorbic acid as a reductant. The $\mathrm{Mo}(\mathrm{V})$ formed a yellow-coloured $(1: 2)$ complex with 6-chloro-3-hydroxy-2-(3' -hydroxyphenyl)-4-oxo-4H-1-benzopyran (CHHB). The complex was quantitatively extracted into toluene and absorbed maximum at $\lambda_{\max } 404 \mathrm{~nm}$. Beer's law was obeyed over the concentration range of $2.31 \mu \mathrm{g} \mathrm{Mo} \mathrm{ml}^{-1}$ with a molar absorptivity and Sandell's sensitivity of $5.62 \times 10^{4} \mathrm{~L} \mathrm{~mol}^{-1} \mathrm{~cm}^{-1}$ and $0.0016 \mu \mathrm{g} \mathrm{Mo} \mathrm{cm}{ }^{-2}$, respectively. The relative standard deviation was 0.0025 (in absorbance units) for 10 replicate determinations of $1 \mu \mathrm{g} \mathrm{Mo} \mathrm{ml} l^{-1}$. The method was free from the interference of large number of analytically important elements. Molybdenum has been determined satisfactorily in different technical, synthetic, and environmental samples with improved accuracy and precision.

\section{Introduction}

Besides the important applications of molybdenum in metallurgy and agriculture, it plays a vital role in different biological processes [1]. Recently, it has been found that some Mo complexes show biocidal activity [2]. Antimicrobial screening data revealed that metal chelates are more potent than the parent ligands. Some studies have shown that molybdenum is an important element in preserving healthy teeth. The amount of molybdenum in soils and plants has been found to be a critical factor in recent years. It is essential to all living organisms at trace levels, especially plants $[3,4]$, animals [3, 4], and microorganisms [4]. The concentration level of molybdenum in water samples is important from both environmental and chemical point of view [3]. Elevated contents of molybdenum in the environment can be toxic to humans, animals, and plants $[5,6]$. For instance, $\mathrm{Mo}(\mathrm{VI})$ ions can decrease catalase activity, which leads to podagric syndrome due to the increase in uric acid concentration in organisms. These ions also raise blood pressure and reduce cholesterol transportation [7]. Molybdenum at the level of
$5 \mathrm{mg} \mathrm{L}^{-1}$ inhibits self-purification processes of natural water and its higher content in water prevents growth of some microorganisms [3].

The great importance of molybdenum in microbiology, industry, and agriculture necessitates development of a rapid, sensitive, accurate, and precise method for its determination at trace levels. Spectrophotometric and atomic emission or atomic absorption methods are most commonly used for this purpose. However, spectrophotometric methods are generally preferred, as they involve less expensive instrumentation and afford better sensitivity when appropriate chromogenic reagents and solvent extraction preconcentration steps are employed. Several analytical methods for determination of molybdenum using different reagents $[2,8,9]$ like chromone derivatives $[10,11]$ have been reported. These methods, however, suffer from a large number of interferences [11-14] and low sensitivity $[2,8-16]$ due to which they are unsuitable for the routine determination of molybdenum in the samples with diverse matrices.

For this purpose, the exhaustive survey of literature was carried out which revealed that chromones form coloured 
complexes with hexavalent molybdenum where some analytically important ions such as $\mathrm{Fe}(\mathrm{III}), \mathrm{Cr}(\mathrm{VI}), \mathrm{V}(\mathrm{V})$, and so forth. interfere seriously. Such interferences can be overcome when some suitable reducing agent is used which reduces these ions to such a state that dose not give any colour reaction with the reagent used. During this study we have observed that 6-chloro-3-hydroxy-2-( $3^{\prime}$-hydroxyphenyl)-4oxo-4H-1-benzopyran (CHHB), compared to all abovementioned chromones, undergoes sensitive and highly selective reaction with molybdenum $(\mathrm{V})$. The reaction is free from the influence of several common interferences.

Molybdenum(VI) is reduced quantitatively with ascorbic acid in sulfuric acid medium at the room temperature to molybdenum(V) which forms an intense yellow coloured complex with $\mathrm{CHHB}$, which is completely extracted into toluene. This forms the basis of the proposed extractive spectrophotometric method for determination of molybdenum after its extraction in the form of $\mathrm{Mo}(\mathrm{V})-\mathrm{CHHB}$ complex. The method has been successfully applied to the analysis of a large variety of samples with diverse matrices such as steels, reverberatory flue dusts, different types of water samples including industrial effluents, and a wide variety of synthetic samples.

\section{Experimental}

2.1. Apparatus, Solutions, and Reagents. An Elico SL164 double beam UV-VIS spectrophotometer with $10 \mathrm{~mm}$ matched quartz cells was used for absorbance measurements.

A stock solution $\left(10 \mathrm{mg} \mathrm{Mo} \mathrm{mL}^{-1}\right)$ was prepared by dissolving an accurately weighed amount of sodium molybdate dihydrate (Baker, A.R.) in deionized water and was standardized using the oxine method [17]. Working standard solutions ( $\mu \mathrm{g} \mathrm{Mo} \mathrm{mL}{ }^{-1}$ concentration level) were obtained by suitable dilutions of the stock solution. Solutions of diverse metal ions for interference studies were prepared by dissolving their salts (A.R.) in deionised water or diluted acids.

Ascorbic acid (Baker, A.R.) was dissolved in deionized water to get $5 \%(\mathrm{w} / \mathrm{v})$ concentration.

$10 \mathrm{M} \mathrm{H}_{2} \mathrm{SO}_{4}$ solution was obtained by suitable dilution of $17.8 \mathrm{M} \mathrm{H}_{2} \mathrm{SO}_{4}$ (Ranbaxy, density $1.84 \mathrm{~g} \mathrm{~mL}^{-1}$ ).

6-Chloro-3-hydroxy-2-(3' -hydroxyphenyl)-4-oxo-4H1-benzopyran $(\mathrm{CHHB})$ was synthesized by the literature method [18] and dissolved in ethanol to give $0.1 \%(\mathrm{w} / \mathrm{v})$ solution.

\subsection{Synthesis of CHHB Involves the following Two Steps}

Step 1 . To the solution of potassium hydroxide $(0.03 \mathrm{moL})$ in methanol $(50 \mathrm{~mL})$ 6-chloro-2-hydroxyacetophenone $(0.01 \mathrm{moL})$ and $m$-hydroxybenzaldehyde $(0.011 \mathrm{moL})$ were added under stirring. Thereafter, the mixture was poured onto ice and neutralized with diluted $\mathrm{HCl}$ to obtain 3-(3'hydroxyphenyl)- $2^{\prime}$-hydroxy $-5^{\prime}$-chloroacrylophenone, which was crystallized from ethanol.

Step 2. Methanolic solution of 3-( $3^{\prime}$-hydroxyphenyl)- $2^{\prime}-$ hydroxy- $5^{\prime}$-chloroacrylo-phenone $(0.01 \mathrm{moL}$ in $40 \mathrm{~mL}$ of methanol) and aqueous solution of $\mathrm{NaOH}(20 \%, 10 \mathrm{~mL})$ were mixed and cooled to $0^{\circ} \mathrm{C}$. To the get dark-red slurry $\mathrm{H}_{2} \mathrm{O}_{2}(30 \%, 5 \mathrm{~mL})$ was added dropwise under stirring at temperature below $10^{\circ} \mathrm{C}$. The resulting light-yellow reaction mixture was poured onto crushed ice and neutralized with diluted $\mathrm{HCl}$. The light-yellow precipitate of $\mathrm{CHHB}$ thus obtained was filtered, washed with water, and crystallized from DMSO-ethanol mixture to give crystalline CHHB (m.p. $181-182^{\circ} \mathrm{C}, 82 \%$ yield).

Toluene (Qualigens, SQ) was distilled and the fraction distilling at $110.6^{\circ} \mathrm{C}$ was collected for extraction.

\section{Samples}

3.1. Synthetic Samples. Molybdenum solutions are mixed with solutions of other diverse metal ions in suitable proportions to get the synthetic samples of desired composition.

3.2. Steel Samples. Steel sample $(0.1 \mathrm{~g})$ was dissolved in $3 \mathrm{~mL}$ of concentrated $\mathrm{HCl}$ and $1 \mathrm{~mL}$ of concentrated $\mathrm{HNO}_{3}$ under slow heating on a sand bath. The solution was evaporated to dryness. Cold residue was treated with $10 \mathrm{~mL}$ of deionised water, acidified, and dissolved in $100 \mathrm{~mL}$ of $1.0 \mathrm{M} \mathrm{H}_{2} \mathrm{SO}_{4}$. For determination of molybdenum content in the steel sample by the proposed method, $4 \mathrm{~mL}$ aliquots of BCS 261/1 solution, $1 \mathrm{~mL}$ aliquots of BCS 406/1 solution, or $2 \mathrm{~mL}$ aliquots of BCS 219/4 solution were taken each time.

3.3. Well Water. $10 \mathrm{~mL}$ of well water sample were mixed with the known amount of molybdenum $(20 \mu \mathrm{g}), 20 \mathrm{~mL}$ of $\mathrm{H}_{2} \mathrm{O}_{2}$, and $2 \mathrm{~mL}$ of aqueous ammonia. The contents were then boiled and evaporated to dryness. The residue was dissolved in $5 \mathrm{~mL}$ of $2 \mathrm{M} \mathrm{H}_{2} \mathrm{SO}_{4}$ and subjected to the analysis for Mo by the proposed method.

3.4. Reverberatory Flue Dust. Flue dust sample ( $0.1 \mathrm{~g})$ from copper manufacture, containing no molybdenum, was mixed with the solution of the known molybdenum content $(1 \mathrm{mg})$ and dried in an oven. After fusion of the dried dust sample with sodium peroxide $(0.8 \mathrm{~g})$, the leach was neutralized with concentrated $\mathrm{H}_{2} \mathrm{SO}_{4}$, made slightly alkaline with aqueous ammonia, boiled, and the hydroxide precipitate was filtered and washed well with deionised water. The filtrate volume was raised to $100 \mathrm{~mL}$ with $1 \mathrm{M} \mathrm{H}_{2} \mathrm{SO}_{4}$. Each time $2 \mathrm{~mL}$ aliquots of this solution were taken for the analysis for Mo by the proposed method.

3.5. Industrial Effluent. Industrial effluent sample (1 L) collected from the main outlet of effluents of metal industries located in twin cities: Yamuna Nagar and Jagadhari, was mixed with a solution of the known molybdenum content (2 mg). To the $10 \mathrm{~mL}$ aliquot of this solution, $1 \mathrm{~mL}$ of hydrogen peroxide and $2 \mathrm{~mL}$ of aqueous ammonia were added. The resulting solution was then boiled and evaporated to dryness. The resulting mass was leached with $5 \mathrm{~mL}$ of $2 \mathrm{M} \mathrm{H}_{2} \mathrm{SO}_{4}$ and subjected to determination of Mo by the proposed procedure.

3.6. Canal Water. To a $100 \mathrm{~mL}$ water sample taken from the Western Yamuna Canal at Yamuna Nagar site, the known 
amount of molybdenum ( $0.5 \mathrm{mg}), 1 \mathrm{~mL}$ of hydrogen peroxide and $2 \mathrm{~mL}$ of aqueous ammonia were added. The contents were then boiled and evaporated to dryness. The residue was dissolved in $2 \mathrm{M} \mathrm{H}_{2} \mathrm{SO}_{4}$ and the final volume was raised to $100 \mathrm{~mL}$. Aliquots of $3 \mathrm{~mL}$ were subjected to the analysis for Mo by the proposed method.

\section{Procedure}

An aliquot of the sample solution $(1 \mathrm{~mL})$ containing $\leq 23.1 \mu \mathrm{g}$ of Mo was taken in a $100 \mathrm{~mL}$ capacity separatory funnel to which are added other metal ions, $1 \mathrm{~mL}$ of $10 \mathrm{M} \mathrm{H}_{2} \mathrm{SO}_{4}, 2 \mathrm{~mL}$ of $5 \%$ ascorbic acid, $1 \mathrm{~mL}$ of $0.1 \%(\mathrm{w} / \mathrm{v})$ ethanolic solution of $\mathrm{CHHB}$ and deionised water to raise the final volume to $10 \mathrm{~mL}$. The contents were mixed gently and equilibrated with the equal volume $(10 \mathrm{~mL})$ of toluene for $30 \mathrm{~s}$. After equilibration, the two phases were allowed to separate and the organic phase was collected into a $10 \mathrm{~mL}$ measuring flask after passing through a piece of a Whatman filter paper no.41 $(9 \mathrm{~cm}$, pretreated with toluene) to remove water droplets. The absorbance of the extract was measured at $404 \mathrm{~nm}$ against the reagent blank (prepared similarly). The molybdenum content was calculated from the calibration curve drawn under identical conditions.

4.1. Modification for $\mathrm{Fe}, \mathrm{Cr}, \mathrm{V}, \mathrm{Zr}, \mathrm{Ti}, \mathrm{Ta}, \mathrm{Nb}$, and $\mathrm{W}$. For each $1 \mathrm{mg} / \mathrm{mL}$ of $\mathrm{Fe}(\mathrm{III}), \mathrm{Cr}(\mathrm{VI})$, and $\mathrm{V}(\mathrm{V})$ an additional amount $(10 \mathrm{mg})$ of ascorbic acid was added before the addition of the reagent. Interference due to $0.5 \mathrm{mg} / \mathrm{mL}$ each of $\mathrm{Zr}(\mathrm{IV})$ and $\mathrm{Ti}(\mathrm{IV}), 0.03 \mathrm{mg} / \mathrm{mL}$ each of $\mathrm{Ta}(\mathrm{V})$ and $\mathrm{Nb}(\mathrm{V})$ and $0.02 \mathrm{mg} / \mathrm{mL}$ of W(VI) can be removed by adding $2 \mathrm{mg} / \mathrm{mL}$ of sodium fluoride as a masking agent for each interferent well before the addition of reagent solution.

\section{Results and Discussion}

In an alkaline medium 6-chloro-3-hydroxy-2-( $3^{\prime}$-hydroxyphenyl)-4-oxo-4H-1-benzopyran (CHHB) itself imparts a dark-yellow colour which is not extracted into organic solvents. In a neutral medium, Mo(VI) forms a light-coloured complex with the reagent. However, in acidic media an intense yellow complex is formed, which is highly extractable into organic solvents. Many other metal ions of analytical importance such as $\mathrm{Fe}(\mathrm{III}), \mathrm{Cr}(\mathrm{VI})$, and $\mathrm{V}(\mathrm{V})$ also form extractable coloured products. But it has been observed that these do not interfere in their lower oxidation states. The reagent also combines with $\mathrm{Mo}(\mathrm{V})$ obtained by ascorbic acid reduction [20] in $1 \mathrm{M} \mathrm{H}_{2} \mathrm{SO}_{4}$ and forms a more intensely coloured complex having an absorption maximum at $404 \mathrm{~nm}$. The complex is quantitatively $(100 \%)$ extracted into toluene and is stable for more than 8 hours. However, pentavalent molybdenum can be also obtained by reduction of $\mathrm{Mo}(\mathrm{VI})$ with different reducing agents, such as hydrazine sulfate, $\mathrm{Sn}(\mathrm{II})-\mathrm{HCl}$, thiourea, dithionite, and $\mathrm{Zn}$-amalgam. Reduction with hydrazine sulphate in $1 \mathrm{M}$ $\mathrm{HCl}$ and $\mathrm{H}_{2} \mathrm{SO}_{4}$ media is not advantageous as it gives low absorbance. Reduction by $\mathrm{Sn}(\mathrm{II})-\mathrm{HCl}$ is not quantitative and furthermore $\mathrm{Sn}(\mathrm{II})$ interferes seriously during determination of molybdenum due to formation of a highly extractable (more than 90\%) greenish-yellow complex with the reagent. Very low absorption values are obtained when reduction is carried out with thiourea, dithionite, and $\mathrm{Zn}$-amalgam due to the reduction of molybdenum to lower oxidation states. The extraction behaviour of the $\mathrm{Mo}(\mathrm{V})$-CHHB complex has been studied under the optimum conditions of the proposed procedure. A large number of organic solvents, namely toluene, dichloromethane, 1,2-dichloroethane, benzene, carbon tetrachloride, chloroform, isopentyl acetate, butyl acetate, ethyl acetate, isobutyl methyl ketone, diethyl ether, isopentyl alcohol, cyclohexane, and 1-butanol were used for extraction of the complex but its absorbance has been found to decrease in the above series. Extraction in toluene was found to be quantitative (100\%) with satisfactory sensitivity and stability of the colour for 8 hours. The raffinate was found devoid of molybdenum after single extraction. The absence of molybdenum in the raffinate was confirmed by more sensitive pyrogallol-thiocyanate method [21]. Hence, toluene was selected as the solvent for further studies.

The effect of different variables on the absorbance of the $\mathrm{Mo}(\mathrm{V})$-CHHB complex was studied by keeping concentration of molybdenum at $1.04 \times 10^{-5} \mathrm{M}$. During this study the conditions were as mentioned in the procedure, except for the relevant parameter, which was varied as shown in Table 1.

In presence of ascorbic acid as the reductant, the metal complex has maximum absorbance in $1 \mathrm{M}$ acidic aqueous phase with $\mathrm{H}_{2} \mathrm{SO}_{4}$ and $\mathrm{HCl}$. However, the absorbance was fund to be much lower in case of $\mathrm{CH}_{3} \mathrm{COOH}$ and $\mathrm{H}_{3} \mathrm{PO}_{4}$. As compared to $\mathrm{HCl}$ medium, the colour was more stable in $\mathrm{H}_{2} \mathrm{SO}_{4}$ medium for both the reduction and extraction step, and hence it was used in further studies. Therefore, the influence of $\mathrm{H}_{2} \mathrm{SO}_{4}$ concentration on the reduction and extraction behaviour and, consequently, on the absorbance of complex in the extract was studied. The maximum and constant absorbance was achieved when $\mathrm{Mo}(\mathrm{VI})$ was reduced by ascorbic acid in an aqueous phase containing 0.5-2.2 M $\mathrm{H}_{2} \mathrm{SO}_{4}$ and the complex was extracted quantitatively at $0.2-2.0 \mathrm{M} \mathrm{H}_{2} \mathrm{SO}_{4}$ acidity. Therefore, in further studies both reduction and extraction steps were carried out in the presence of $1 \mathrm{M} \mathrm{H}_{2} \mathrm{SO}_{4}$.

During the study of effect of concentration of the reductant a constant and maximum absorbance was obtained for $0.15-2.5 \mathrm{~mL}$ of $5 \%(\mathrm{w} / \mathrm{v})$ ascorbic acid solution in $10 \mathrm{ml}$ of the aqueous phase. Larger amounts of the reductant decreases the absorbance significantly. Hence, for further investigations $2 \mathrm{~mL}$ of $5 \%(\mathrm{w} / \mathrm{v})$ ascorbic acid was used.

The study of the effect of the reagent concentration on the absorbance of the extracted species was carried out by measuring the absorbance of the complex at $404 \mathrm{~nm}$ against the similarly prepared reagent blank. It has been found that the reagent blank absorbs negligibly at lower concentration level of the reagent but it starts absorbing to some extent at higher concentration levels. The absorbance of the complex in the extract increased initially with an increase in the reagent concentration and reached a constant value for $0.6-1.6 \mathrm{~mL}$ of $0.1 \%(\mathrm{w} / \mathrm{v})$ ethanolic solution of CHHB in a single extraction. However, high concentration of the reagent decreased significantly the absorbance values due to 
TABLE 1: Effect of various parameters on the absorbance of $\mathrm{Mo}(\mathrm{V})$-CHHB complex.

\begin{tabular}{|c|c|c|c|c|c|}
\hline $\mathrm{H}_{2} \mathrm{SO}_{4}{ }^{a} / \mathrm{M}$ & 0.01 & 0.05 & 0.2 & $0.5-2.2$ & 3.0 \\
\hline Absorbance & 0.390 & 0.520 & 0.555 & 0.586 & 0.574 \\
\hline $\mathrm{H}_{2} \mathrm{SO}_{4}^{\mathrm{b}} / \mathrm{M}$ & 0.01 & 0.05 & $0.2-2.0$ & 2.5 & 3.0 \\
\hline Absorbance & 0.322 & 0.510 & 0.586 & 0.563 & 0.535 \\
\hline $5 \%$ ascorbic $\operatorname{acid}^{\mathrm{c}} / \mathrm{M}$ & 0.0 & 0.1 & $0.15-2.5$ & 3.0 & 4.0 \\
\hline Absorbance & 0.533 & 0.575 & 0.586 & 0.561 & 0.547 \\
\hline $0.1 \% \mathrm{CHHB}^{\mathrm{d}} / \mathrm{mL}$ & 0.1 & 0.3 & 0.5 & $0.6-1.5$ & 2.0 \\
\hline Absorbance & 0.090 & 0.320 & 0.410 & 0.586 & 0.565 \\
\hline Equilibration time ${ }^{\mathrm{e}} / \mathrm{s}$ & 3 & 5 & $10-180$ & 250 & 300 \\
\hline Absorbance & 0.290 & 0.455 & 0.586 & 0.560 & 0.532 \\
\hline
\end{tabular}

${ }^{a}$ Conditions: $\mathrm{Mo}=1 \mathrm{~mL}$ of $1.0423 \times 10^{-4} \mathrm{M}$ solution; $5 \%$ ascorbic acid $=2 \mathrm{~mL} ; \mathrm{CHHB}[0.1 \%(\mathrm{w} / \mathrm{v})$ in ethanol $]=1 \mathrm{~mL}$; aqueous volume $=$ organic solvent volume $=10 \mathrm{~mL}$; organic solvent $=$ toluene; equilibration time $=30 \mathrm{~s}$; number of extractions $=1$.

${ }^{\mathrm{b}}$ Conditions: $10 \mathrm{M} \mathrm{H}_{2} \mathrm{SO}_{4}=1 \mathrm{~mL}$; other conditions are the same as in (a) except for $\mathrm{H}_{2} \mathrm{SO}_{4}$ content before extraction.

${ }^{\mathrm{c}}$ Conditions: other conditions are same as in (a) excepting variation in ascorbic acid content.

${ }^{\mathrm{d}}$ Conditions: $5 \%(\mathrm{w} / \mathrm{v})$ ascorbic acid $=2 \mathrm{~mL}$; other conditions are the same as in (a) except for CHHB content; absorbance is measured against the reagent blank.

${ }^{\mathrm{e}}$ Conditions: $\mathrm{CHHB}[0.1 \%(\mathrm{w} / \mathrm{v})$ in ethanol $]=1 \mathrm{~mL}$; other conditions are the same as in (a) except for equilibration time.

the appearance of turbidity in the reagent blank. Hence, $1 \mathrm{ml}$ of $0.1 \%(\mathrm{w} / \mathrm{v})$ reagent was used for further studies.

Under optimum conditions the absorbance of the complex formed in the aqueous phase after equilibration with toluene increased initially and then achieved a constant and maximum value for $10-180 \mathrm{~s}$. Therefore, $30 \mathrm{~s}$ was selected as the optimum equilibration time for each extraction during further studies and has been used in the proposed procedure.

Based upon the above study optimum conditions providing maximum, stable and reproducible absorbance values were selected and incorporated in the proposed procedure.

5.1. Spectral Characteristics. The absorption spectrum of yellow coloured $\mathrm{Mo}(\mathrm{V})-\mathrm{CHHB}$ complex recorded against the reagent blank under optimum conditions showed that the extracted species absorbs maximum at $404 \mathrm{~nm}\left(\lambda_{\max }\right)$. The reagent blank absorbed negligibly in this region. Therefore, absorbance measurements were carried out at $404 \mathrm{~nm}$ against the pure solvent.

5.2. Beer's Law, Standard Deviation, and Sensitivity. Beer's law was obeyed over the concentration range of molybdenum up to $2.31 \mu \mathrm{g} / \mathrm{mL}$ of the solvent phase. However, study of Ringbom curve [22] indicated that the practical range for accurate determination of molybdenum was $0.75-1.80 \mu \mathrm{g} / \mathrm{mL}$ at $404 \mathrm{~nm}$. Molar absorptivity and Sandell's sensitivity of the procedure were $5.62 \times 10^{4} \mathrm{~L} \mathrm{moL}^{-1} \mathrm{~cm}^{-1}$ and $0.0016 \mu \mathrm{g} \mathrm{Mo} \mathrm{cm}^{-2}$, respectively. The relative standard deviation was found to be 0.0025 (absorbance units) for 10 replicate determinations of $1 \mu \mathrm{g} \mathrm{Mo} \mathrm{mL}{ }^{-1}$.

5.3. Stoichiometry of the Complex. The stoichiometry of the $\mathrm{Mo}(\mathrm{V})$ : $\mathrm{CHHB}$ complex was determined by Job's method of continuous variations, as modified by Vosburgh and Cooper for the two-phase systems (Figure 1). The absorbance values were recorded at two wavelengths, namely, 404 and $420 \mathrm{~nm}$. The curves obtained were indicative of $1: 2$ stoichiometry of the extracted species. This stoichiometric ratio was further confirmed by the mole-ratio method [22] at two different

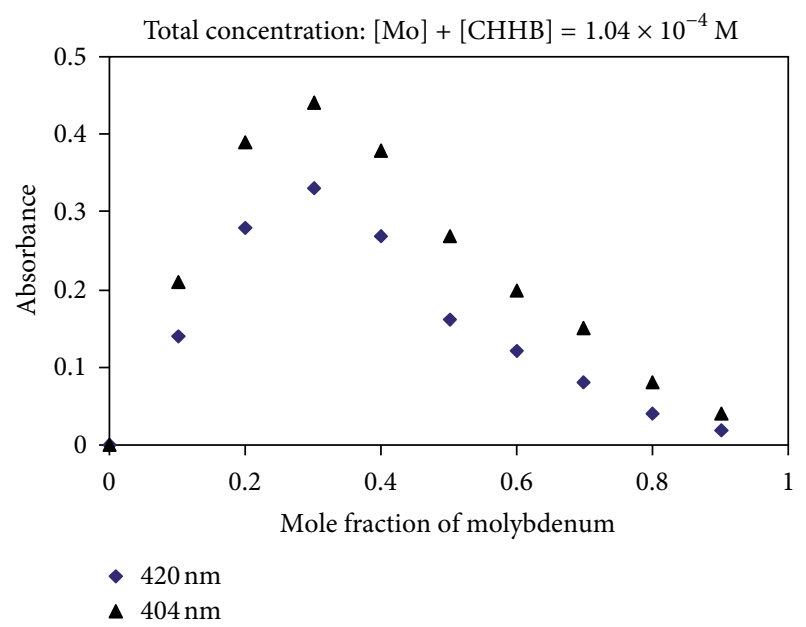

FIGURE 1: Job's method of continuous variations.

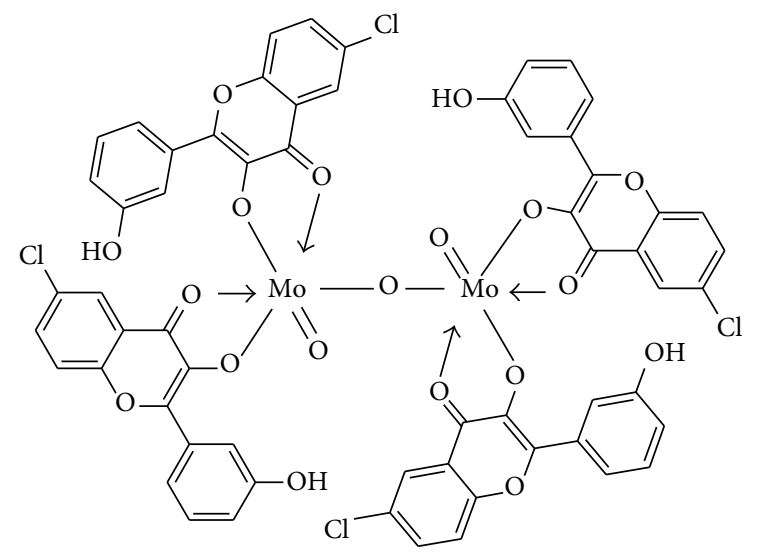

FIgURE 2: Chemical structure of the Mo(V)-CHHB complex.

concentrations of molybdenum $\left(2.0 \times 10^{-5}\right.$ and $\left.3.0 \times 10^{-5} \mathrm{M}\right)$ and measuring the absorbance of each at both wavelengths 404 and $420 \mathrm{~nm}$. Based upon the above stoichiometry, the possible structure of the complex was proposed (molecular formula: $\mathrm{Mo}_{2} \mathrm{O}_{3}\left(\mathrm{C}_{19} \mathrm{H}_{15} \mathrm{O}_{5}\right)_{4}$ in the organic phase, Figure 2). 
TABLE 2: Comparison of the proposed method with the existing methods of molybdenum determination.

\begin{tabular}{|c|c|c|c|c|c|}
\hline $\begin{array}{l}\text { Sr. } \\
\text { no. }\end{array}$ & Aqueous conditions (initial) & $\begin{array}{l}\text { (i) Solvent } \\
\text { (ii) } \lambda_{\max }(\mathrm{nm})\end{array}$ & $\begin{array}{l}\text { (i) Molar absorptivity }\left(\mathrm{L} \mathrm{mol}^{-1} \mathrm{~cm}^{-1}\right) \\
\text { (ii) Sandell's sensitivity }\left(\mu \mathrm{g} \mathrm{Mo} \mathrm{cm}^{-2}\right)\end{array}$ & $\begin{array}{l}\text { Beer's law range } \\
\left(\mu \mathrm{g} \mathrm{Mo} \mathrm{mL}^{-1}\right)\end{array}$ & Reference no. \\
\hline (1) & Mo(VI), pH 1.5, 3-hydroxyflavone & $\begin{array}{l}\text { (i) } \mathrm{C}_{6} \mathrm{H}_{6} \\
\text { (ii) } 400\end{array}$ & $\begin{array}{l}\text { (i) } 3.7 \times 10^{4} \\
\text { (ii) } 0.0026\end{array}$ & $0.05-2.2$ & {$[10]$} \\
\hline (2) & $\begin{array}{l}\mathrm{Mo}(\mathrm{VI}) \text {, acetic acid, } \mathrm{pH} 4.2-2.9,2-\left(2^{\prime}-\right. \\
\text { furyl)-3-hydroxy-4H-chromen-4-one }\end{array}$ & $\begin{array}{l}\text { (i) } \mathrm{CHCl}_{3} \\
\text { (ii) } 414\end{array}$ & $\begin{array}{l}\text { (i) } 4.99 \times 10^{4} \\
\text { (ii) } 0.0019\end{array}$ & $0-2.9$ & {$[12]$} \\
\hline (3) & $\mathrm{Mo}(\mathrm{VI}), \mathrm{HCl}, \alpha$-benzoinoxime, quercetin & $\begin{array}{l}\text { (i) } \mathrm{CHCl}_{3} \\
\text { (ii) } 420\end{array}$ & $\begin{array}{l}\text { (i) } 3.6 \times 10^{4} \\
\text { (ii) } 0.0027\end{array}$ & $0.6-1.8$ & {$[14]$} \\
\hline (4) & $\begin{array}{l}\mathrm{Mo}(\mathrm{VI}), \mathrm{pH} 3-5 \\
\text { 3,4-dihydroxy-benzaldehyde } \\
\text { thiosemicarbazone }\end{array}$ & $\begin{array}{l}\text { (i) }- \\
\text { (ii) } 365\end{array}$ & $\begin{array}{l}\text { (i) } 3.85 \times 10^{4} \\
\text { (ii) } 0.0025\end{array}$ & $0.19-1.34$ & {$[9]$} \\
\hline (5) & $\begin{array}{l}\mathrm{Mo}(\mathrm{V}), \mathrm{SCN}^{-}, \mathrm{HCl} \text {, chloroquine and } \\
\mathrm{Mo}(\mathrm{V}), \mathrm{SCN}^{-}, \mathrm{HCl} \text {, pyrimethamine }\end{array}$ & $\begin{array}{l}\text { (i) } \mathrm{CH}_{2} \mathrm{Cl}_{2} \\
\text { (ii) } 467 \text { and } 471\end{array}$ & $\begin{array}{l}\text { (i) } 6.16 \times 10^{3} \text { and } 5.8 \times 10^{3} \\
\text { (ii) } 0.027 \text { and } 0.042\end{array}$ & $\begin{array}{l}2.0-2.2 \\
2.0-25\end{array}$ & {$[19]$} \\
\hline (6) & $\begin{array}{l}\mathrm{Mo}(\mathrm{VI}), 1 \mathrm{M} \mathrm{H}_{2} \mathrm{SO}_{4} \text {, Ascorbic acid, } \\
\text { CHHB }\end{array}$ & $\begin{array}{l}\text { (i) Toluene } \\
\text { (ii) } 404\end{array}$ & $\begin{array}{l}\text { (i) } 5.26 \times 10^{4} \\
\text { (ii) } 0.0016\end{array}$ & $0-2.31$ & $\begin{array}{l}\text { Proposed } \\
\text { method }\end{array}$ \\
\hline
\end{tabular}

TABLE 3: Analysis of molybdenum samples by the proposed method.

\begin{tabular}{|c|c|c|c|}
\hline \multirow{2}{*}{ Sr. no. } & \multicolumn{2}{|c|}{ Composition of sample } & \multirow{2}{*}{ Mo found ${ }^{b} / \mu g$} \\
\hline & Matrix $^{\mathrm{a}}$ & Mo added $/ \mu \mathrm{g}$ & \\
\hline 1 & $\mathrm{Fe}(0.3), \operatorname{Th}(0.1), \mathrm{U}(0.9), \mathrm{Cr}(0.5)$ & 15 & 14.93 \\
\hline 2 & $\mathrm{Zn}(0.6), \mathrm{Co}(1.5), \mathrm{Cu}(2)$ & 20 & 20.10 \\
\hline 3 & $\mathrm{Zn}(5), \mathrm{Cu}(2.5), \mathrm{Mn}(5), \mathrm{V}(1)$ & 20 & 20.00 \\
\hline 4 & $\operatorname{Re}(0.1), \operatorname{Ag}(1.5), \mathrm{Ba}(4), \mathrm{Co}(2)$ & 15 & 14.90 \\
\hline 5 & $\operatorname{Ti}(0.01), \operatorname{Cr}(0.5), \mathrm{Cu}(0.5), \mathrm{Fe}(2)$ & 8 & 8.05 \\
\hline 6 & $\operatorname{Pt}(0.1), \mathrm{V}(1.5), \mathrm{Au}(1), \mathrm{Mg}(4)$ & 20 & 21.10 \\
\hline 7 & {$[\mathrm{Co}(0.0004), \mathrm{Cu}(0.0075), \mathrm{Mn}(0.015), \mathrm{Ni}(0.0563), \mathrm{Cr}(0.015), \mathrm{Fe}(0.2175)]^{\mathrm{c}}$} & 15 & 14.90 \\
\hline 8 & {$[\mathrm{Cu}(0.01), \mathrm{Ni}(0.0912), \mathrm{Cr}(0.190), \mathrm{Fe}(0.70)]^{\mathrm{c}}$} & 10 & 10.05 \\
\hline 9 & {$[\mathrm{Mn}(0.033), \mathrm{Ni}(0.33), \mathrm{Cr}(0.4665), \mathrm{Fe}(2.6655)]^{\mathrm{c}}$} & 15 & 15.00 \\
\hline 10 & Well water & 20 & $19.90 \pm 0.19^{\mathrm{d}}$ \\
\hline 11 & Canal water & 15 & $15.15 \pm 0.11^{\mathrm{d}}$ \\
\hline 12 & Industrial effluent & 20 & $20.18 \pm 0.15^{\mathrm{d}}$ \\
\hline 13 & Reverberatory flue dust & 20 & $19.70 \pm 0.11$ \\
\hline 14 & $\operatorname{BCS}(406 / 1)$ & $1.00 \%{ }^{\mathrm{e}}$ & $0.995 \pm 0.015 \%^{\mathrm{d}}$ \\
\hline 15 & $\operatorname{BCS}(261 / 1)$ & $0.11 \%^{\mathrm{e}}$ & $0.106 \pm 0.002 \%^{\mathrm{d}}$ \\
\hline 16 & $\operatorname{BCS}(219 / 4)$ & $0.58 \%{ }^{\mathrm{e}}$ & $0.568 \pm 0.003 \%^{\mathrm{d}}$ \\
\hline
\end{tabular}

\footnotetext{
${ }^{\mathrm{a}}$ Number in brackets indicates mg amounts of elements in the aliquot for analysis.

${ }^{\mathrm{b}}$ Average of triplicate analyses.

${ }^{c}$ Sample nos. 7, 8, and 9 are analogous to stainless steel, stainless $U$, and cast steel, respectively.

${ }^{\mathrm{d}}$ Mean \pm relative standard deviation $(n=6)$.

${ }^{\mathrm{e}}$ Certified value.
}

The probable structure of the complex was supported by the IR spectra, in which a strong band at $945 \mathrm{~cm}^{-1}$ and a weak band at $745 \mathrm{~cm}^{-1}$ were assigned to $\mathrm{Mo}=\mathrm{O}$ absorption and to antisymmetric Mo-O-Mo stretching, respectively. These observations were further confirmed by the similar values obtained for Mo-oxygen bonds in the IR spectra of other $\mathrm{Mo}(\mathrm{V})$ complexes of the similar type. Thus, the studied complex was supposed to contain a linear Mo-O-Mo arrangement with cis terminal oxygen atoms with respect to the bridging oxygen atom.

5.4. Effect of Diverse Ions. Various cations $(\mathrm{mg} / \mathrm{mL}$, numbers given in parentheses), such as $\mathrm{Ba}(\mathrm{II}), \mathrm{Mg}(\mathrm{II}), \mathrm{Ca}(\mathrm{II}), \mathrm{Sr}(\mathrm{II})$,
$\mathrm{Mn}(\mathrm{II}), \mathrm{V}(\mathrm{IV}), \mathrm{Fe}(\mathrm{II}), \mathrm{Cr}(\mathrm{III}), \mathrm{Co}(\mathrm{II}), \mathrm{Cu}(\mathrm{II}), \mathrm{Zn}(\mathrm{II}), \mathrm{Cd}(\mathrm{II})$, $\mathrm{Hg}(\mathrm{II}), \mathrm{As}(\mathrm{V}), \mathrm{Al}(\mathrm{III})$ and $\mathrm{Bi}(\mathrm{III})$ (1.0 each); $\mathrm{Ag}(\mathrm{I})$ (0.6), $\mathrm{Pb}$ (II), U(VI) and Th(IV) (0.5 each); $\mathrm{Ni}(\mathrm{II})$ and $\mathrm{Ce}(\mathrm{IV})(0.21$ each); Rh(III), Os(VIII), Pd(II), Re(VII), Pt(IV), Ru(III), $\mathrm{Au}(\mathrm{III})$, and $\mathrm{Ir}(\mathrm{III})$ (0.020 each, higher amounts were not studied) did not affect the absorbance of $\mathrm{Mo}(\mathrm{V})$ - $\mathrm{CHHB}$ complex when present in $10 \mathrm{~mL}$ of the aqueous phase and were found to cause $<1 \%$ error. However, $\mathrm{Fe}(\mathrm{III}), \mathrm{Cr}(\mathrm{VI}), \mathrm{V}(\mathrm{V})$, $\mathrm{Zr}(\mathrm{IV}), \mathrm{Ti}(\mathrm{IV}), \mathrm{Ta}(\mathrm{V}), \mathrm{Nb}(\mathrm{V})$, and $\mathrm{W}(\mathrm{VI})$ required masking agents, as mentioned under the procedure. $\mathrm{Sn}(\mathrm{II})$ and $\mathrm{Sb}(\mathrm{V})$ interfered seriously even when present at trace level and produce $>1 \%$ error in the determination of molybdenum.

Under the optimum conditions, the effect of various anions, cations, and complexing agents $(\mathrm{mg} / 10 \mathrm{~mL}$, numbers 
given in parenthesis) was studied on the absorbance of $\mathrm{Mo}(\mathrm{V})-\mathrm{CHHB}$ complex by taking $1 \mu \mathrm{g} \mathrm{Mo} / \mathrm{mL}$. Sulfate (100), nitrate (55), chloride (45), acetate and thiourea (30 each), iodide, carbonate and bicarbonate (20 each), bromide, persulfate and borate (10 each), phosphate (3), tartrate and citrate (1.5 each), EDTA (1), fluoride (0.7) and oxalate (0.5) caused $<1 \%$ error. All the anions and complexing agents were added in the form of their solid sodium salts except iodide, persulfate, and bromide, which were added as potassium salts. These diverse ions and complexing agents were added well before the addition of reagent. Glycerol did not interfered up to $0.7 \mathrm{~mL}$. Thiocyanate and hydrogen peroxide were found to cause $>10 \%$ error even when present as traces.

5.5. Applications. The proposed procedure has advantage (Table 2) of better sensitivity, selectivity, rapidity, wider Beer's law range, accuracy $[9-14,19,23-25]$, and applicability to the samples containing several interfering elements in concentrations higher than normally met with [26]. Applicability of the method straightway to the wide variety of technical and synthetic samples, especially varieties of steel, reverberatory flue dust and different types of water samples including industrial effluents with satisfactory accuracy and precision, is shown in Table 3 . The method is simple and requires only 10 min for a single determination and much less for a series operation.

\section{Acknowledgments}

Our sincere thanks are due to the Principal, G. N. K. College, Yamuna Nagar, Director, N.I.T, Kurukshetra, and the Principal, A. K. Mahavidyalya, Shahabad, Haryana, for providing infrastructure and laboratory facilities and to the UGC New Delhi for the financial assistance.

\section{References}

[1] F. A. Cotton, G. Wilkinson, C. A. Murillo, and M. Bochman, Advanced Inorganic Chemistry, Wiley Interscience, New York, NY, USA, 6th edition, 1999.

[2] R. V. Singh, R. Dwivedi, and S. Sharma, "Spectral and biological properties of unsymmetrical imine complexes of dioxomolybdenum(VI) with sulfadrug azomethines and thiosemicarbazone," Journal of the Indian Chemical Society, vol. 81, no. 6, pp. 454-456, 2004.

[3] S. J. N. Burgmayer and E. I. Stiefel, "Molybdenum enzymes, cofactors, and model systems: the chemical uniqueness of molybdenum," Journal of Chemical Education, vol. 62, no. 11, pp. 938-943, 1985.

[4] A. Tunçeli and A. R. Türker, "Solid-phase extraction and spectrophotometric determination of molybdenum(VI) in soil and plant samples as a Mo(V)-thiocyanate complex," Microchimica Acta, vol. 144, no. 1-3, pp. 69-74, 2004.

[5] O. N. Kononova, S. V. Kachin, A. E. Chaikovskaya, A. G. Kholmogorov, and O. P. Kalyakina, "Sorption preconcentration and determination of molybdenum(VI) by diffuse reflection spectroscopy," Turkish Journal of Chemistry, vol. 28, no. 2, pp. 193-202, 2004

[6] S. Langard and T. Norseth, Handbook on the Toxicology of Metals, Elsevier, Amsterdam, the Netherlands, 1986.
[7] A. G. Kholmogorov, O. N. Kononova, G. L. Pashokov, S. V. Kachin, O. N. Panchenko, and O. P. Kalyakina, The European Journal of Mineral Processing and Environmental Protection, vol. 82, no. 2, 2002.

[8] M. R. P. Reddy, P. V. S. Kumar, J. P. Shyamasundar, and Y. Anjaneyulu, "Extractive spectrophotometric determination of molybdenum in steels and nickel base high temperature alloys with hydroxylamine hydrochloride and 4-(2- Pyridylazo) resorcinol," Proceedings of the Indian National Science Academy, vol. 56, no. 3, p. 255, 1990.

[9] B. V. Narayanan, J. Sreenivas, and V. S. Rao, Research Journal of Chemistry and Environment, vol. 10, p. 67, 2006.

[10] S. Rubio-Barroso and L. M. Polo-Diez, Anales de Química B, vol. 83, p. 67, 1987.

[11] G. Goldstein, D. L. Manning, and O. Menis, "Spectrophotometric determination of molybdenum as the quercetin complex in an alpha-benzoinoxime-chloroform-ethyl alcohol medium," Analytical Chemistry, vol. 30, no. 4, pp. 539-542, 1958.

[12] G. Almassy and M. Vigvari, Magyar Kemiai Folyoirat, vol. 62, p. 332, 1956.

[13] F. L. Chan and R. W. Moshier, "Spectrophotometric determination of molybdenum in steel with $3: 3^{\prime}: 4^{\prime}: 5: 7$-pentahydroxyflavanone," Talanta, vol. 3, no. 3, pp. 272-276, 1960.

[14] R. Dass and J. R. Mehta, Bulletin of the Chemical Society of Japan, vol. 66, p. 2251, 1993.

[15] I. Baranowska and K. Barszczewska, "Spectrophotometric and volumetric molybdenum determination with $2,2^{\prime}$-biquinoxalyl," Talanta, vol. 39, no. 9, pp. 1205-1208, 1992.

[16] M. Das, K. S. Patel, and R. K. Mishra, Analysis, vol. 17, p. 536, 1989.

[17] K. Kodama, Methods of Quantitative Inorganic Analysis, Interscience, New York, NY, USA, 1963.

[18] O. V. Singh, [Ph.D. thesis], Kurukshetra University, Kurukshetra, India, 1989.

[19] G. G. Mohamed, S. M. Khalil, and H. M. Elqudaby, "Spectrophotometric microdetermination of $\mathrm{Mo}[\mathrm{V}]$ in pure and in steel using its thiocyanate complex interaction with chloroquine and pyrimethamine reagents," Egyptian Journal of Chemistry, vol. 44, pp. 215-226, 2001.

[20] A. I. Busev, Analytical Chemistry of Molybdenum, Programme for Scientific Translations, Jerusalem, Israel, 1964.

[21] P. Bermajo Barrera, J. F. Vazquez Gonzalex, and F. Bermajo Martinex, "Spectrophotometric determination of molybdenum with thiocyanate and pyrogallol," Microchemical Journal, vol. 35, pp. 1-6, 1987.

[22] J. H. Yoe and A. L. Jones, Industrial and Engineering Chemistry, vol. 16, p. 111, 1944.

[23] H. Onishi, Photometric Determination of Traces of Metals, Chemical Analysis, vol. 3, Wiley, New York, 4th edition, 1989.

[24] A. Mishra and H. Mohabey, Oriental Journal of Chemistry, vol. 17, p. 295, 2001.

[25] Z. Lu, H. Guo, and L. Yao, Lihua Jianyan, Hauxue Fence, vol. 37, p. 427, 2001.

[26] F. D. Snell, Photometric and Fluorometric Methods of AnalysisMetals Part 2, John Wiley and Sons, New York, NY, USA, 1978.

[27] A. Ringbom, Fresenius' Zeitschrift, vol. 115, p. 332, 1938. 

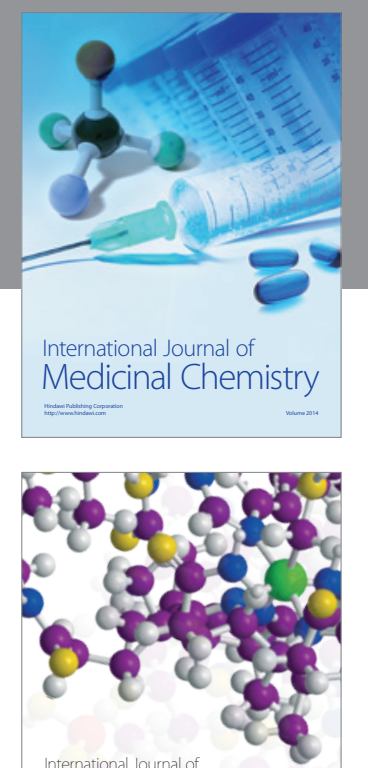

\section{Carbohydrate} Chemistry

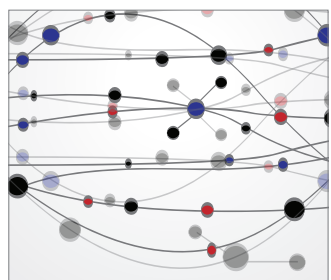

The Scientific World Journal
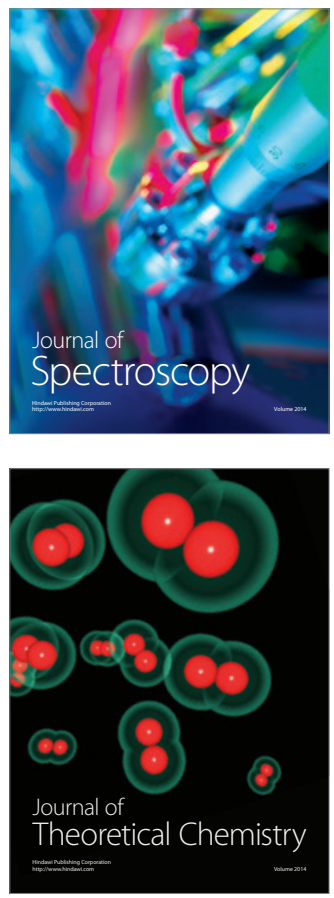
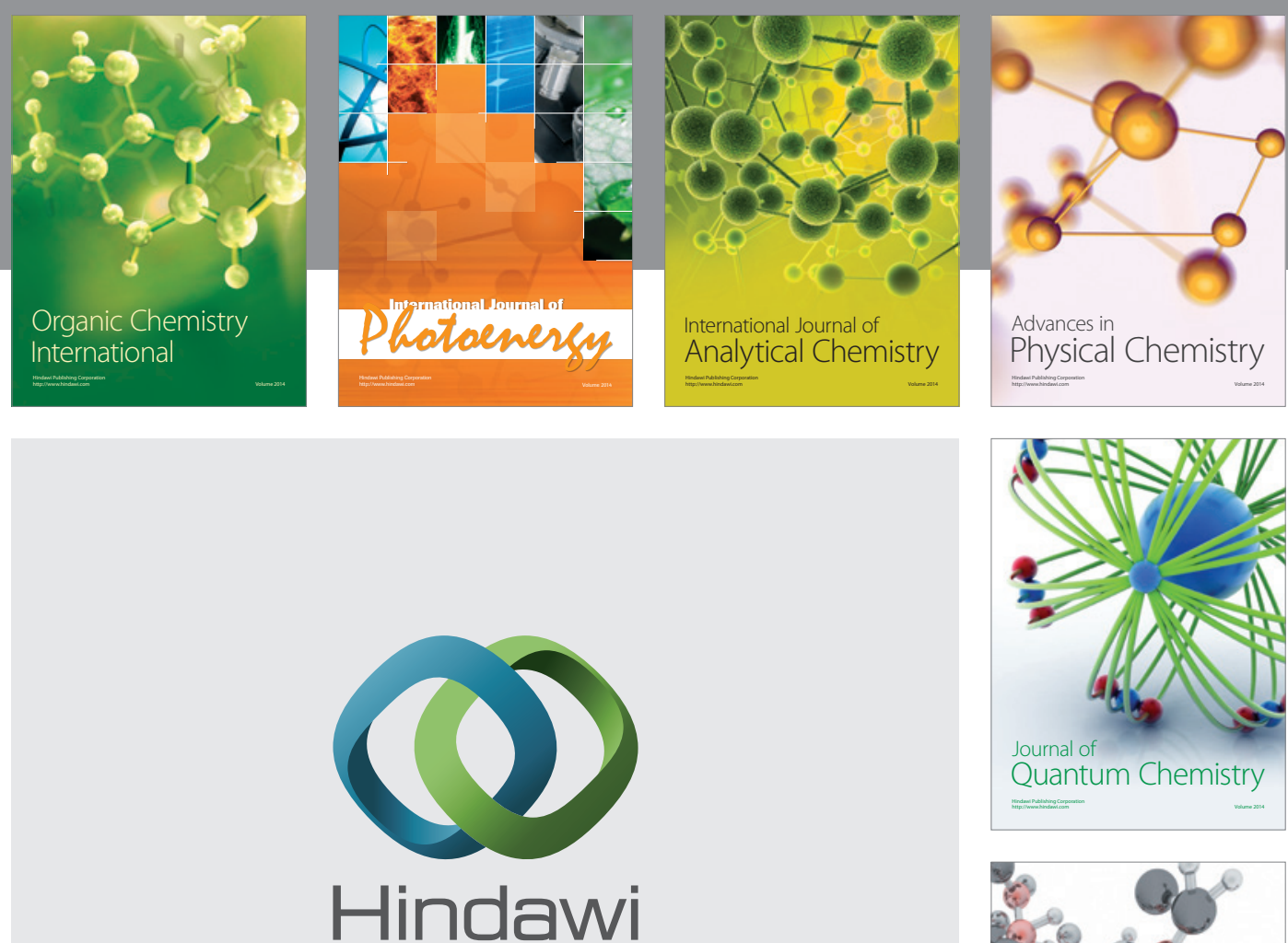

Submit your manuscripts at

http://www.hindawi.com

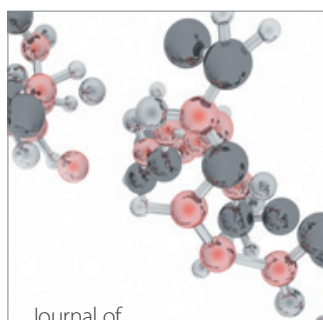

Analytical Methods

in Chemistry

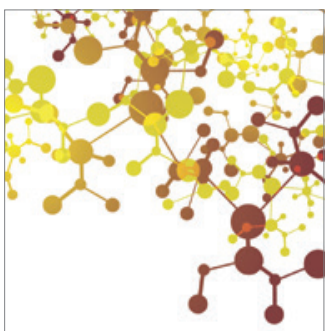

Journal of

Applied Chemistry

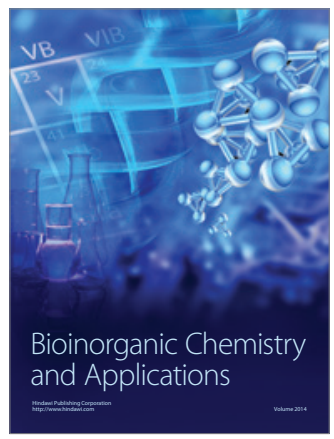

Inorganic Chemistry
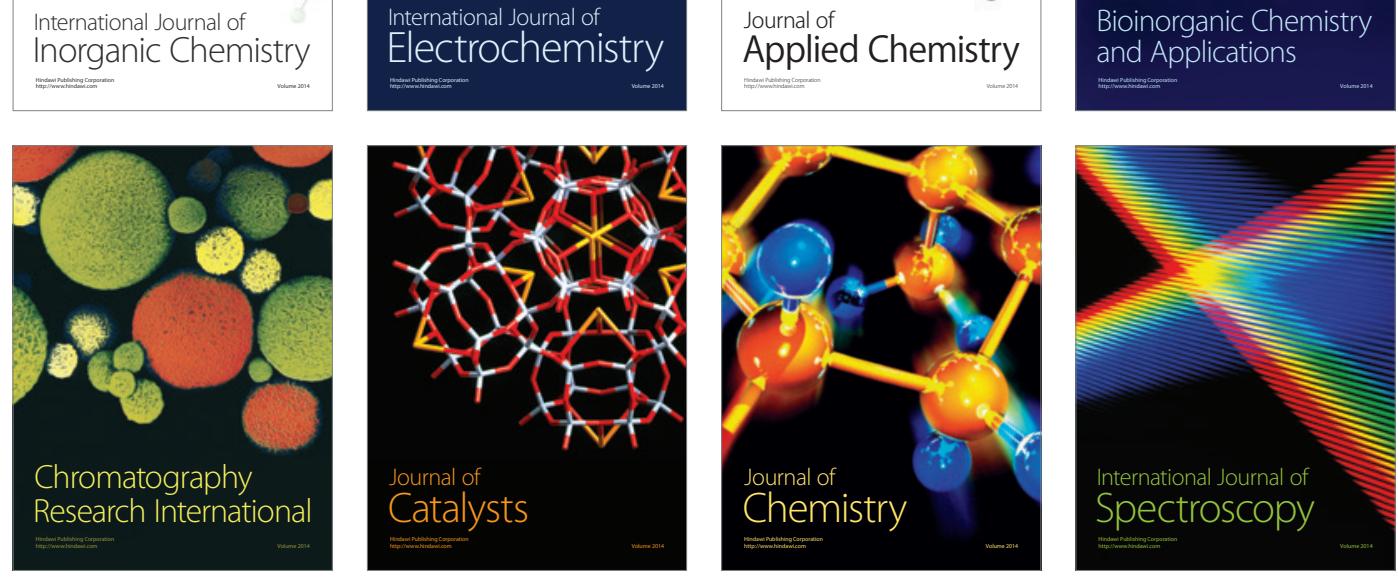